\title{
PENERAPAN METODE LEAN SIX SIGMA DAN THEORY OF INVENTIVE PROBLEM SOLVING UNTUK MENGURANGI WASTE DAN PERBAIKAN KUALITAS DI PT. UNGGUL MAKMUR SEJAHTERA (PT.UMS) LUMAJANG
}

\author{
Mohammad Khusnu Milad \\ Fakultas Sains dan Teknologi UIN Sunan Ampel \\ Jl. Ahmad Yani 117, Surabaya, Indonesia \\ e-mail: penulis1@email.com ${ }^{1)}$, penulis2@email.com ${ }^{2)}$, penulis3@email.com ${ }^{3)}$
}

\begin{abstract}
Abstrak
Persaingan yang semakin kompetitif di pasar global mendorong PT. Unggul Makmur Sejahtera untuk meningkatkan efisiensi produksi khususnya untuk pemakaian sumber daya yang ada. Kriteria pencapaian efisiensi produksi berkaitan erat dengan jumlah pemborosan (waste) yang terjadi di setiap proses produksi. Semakin besar waste yang terjadi akan berakibat terganggunya aktivitas fisik maupun aliran informasi yang berdampak pada tingginya biaya operasional dan tidak tepatnya waktu pemenuhan permintaan konsumen serta kualitas produk yang tidak sesuai dengan ekspektasi konsumen. Oleh karena itu diperlukan sebuah pendekatan untuk mengeliminasi pemborosan yang terjadi dan melakukan perbaikan kualitas, salah satunya dengan pendekatan lean six sigma.

Penelitian ini memfokuskan pada upaya untuk mencari solusi-solusi yang dapat menurunkan jumlah waste dan menghasilkan solusi potensial untuk mengatasi masalah kualitas yang terjadi. Dengan mengikuti metodologi Lean Six Sigma (Define, Measure, Analyze, Improve, Control).

Dalam penelitian ini diperoleh kinerja perusahaan khusus pada PT. Unggul Makmur Sejahtera dalam level sigma sebelum perbaikan sebesar 4 sigma, di mana nilai ini merupakan standar kinerja industri secara internasional. Waste terbesar yang terjadi adalah defect dan unnecessary inventories, yang berasal dari proses injection dan stitching upper. Penyebab utama masalah kualitas adalah over roughing dan 2nd injection. Solusi TRIZ menghasilkan perbaikan adalah berupa implementasi penggunaan alarm dan lampu sebagai signal, penambahan diluents kedalam material, dan pemanasan mould sebelum dipasang pada mesin. Level sigma perusahaan setelah perbaikan mencapai 6 sigma.
\end{abstract}

Kata Kunci: Lean six sigma, TRIZ, garment manufacture, dan waste

\section{Abstract}

Competition in an increasingly competitive global market encourages PT. Unggul Makmur Sejahtera to improve production efficiency, especially for the use of existing resources. Criteria for the achievement of production efficiency is closely related to the amount of waste (waste) that occur in every process of production. The greater the waste that occurs will result in disruption of physical activity and the flow of information that contributes to the high cost of operations and not precisely time the fulfillment of consumer demand as well as quality products that are not in accordance with the expectations of consumers. Therefore we need an approach to eliminate the waste and to improve the quality, one of them with lean six sigma approach.

This study focuses on efforts to find solutions that can reduce the amount of waste and generate potential solutions to overcome quality problems occur. By following the Lean Six Sigma methodology (Define, Measure, Analyze, Improve, Control).

In this research, the performance of the company specialized in PT. Unggul Makmur Sejahtera in sigma level before improvement by 4 sigma, where this value is the international industry performance standards. The biggest waste occurs is defect and unnecessary inventories, which come from the process of injection and upper stitching. The main cause of quality problems are over roughing and 2nd injection. TRIZ solutions result in improved is in the form of implementation of the use of alarms and lights as a signal, the addition of diluents into the material, and heating the mold before being installed on the machine. Level sigma company after achieving six sigma improvement.

Keywords: Lean six sigma, TRIZ, garment manufacturing, and waste 


\subsection{Latar Belakang}

Salah satu permasalahan dari proses industri dalam pasar global yang semakin kompetitif adalah kebutuhan untuk menghasilkan produk dengan kualitas yang tinggi dengan pemakaian energi dan sumber daya yang semakin kecil. Untuk memperbaiki dan meningkatkan proses dalam perusahaan ada banyak sekali metode yang dapat diterapkan. Salah satu metode yang telah diakui kesuksesannya adalah Lean Six Sigma. Konsep Leanadalah perampingan atau efisiensi suatu proses, sedangkan Six Sigma didefinisikan sebagai proses yang tidak memproduksi lebih dari 3,4 produk cacat dalam setiap satu juta peluang $(3,4$ defect per million opportunity), dan usaha untuk mencapai hal tersebut dilakukan 5 fase yang disebut DMAIC (Define, Measure, Analize, Improve, dan Control).

PT. Unggul Makmur Sejahtera adalah sebuah perusahaan Garment yang bediri baru pada tahun 2011 . Sebagai pabrik baru berusaha tumbuh dengan cepat dan terkontrol dengan baik terutama di sktor produksi. Bisnis utamanya adalah pakaian, celana, jacket dengan model utama classic, casual, sports, dan anak-anak. Sistem produksi perusahaan yang sekarang telah mampu memenuhi kebutuhan pelanggan. Akan tetapi jika dilihat dari sisi efisiensi khususnya untuk kebutuhan bahan baku yang digunakan, perusahaan masih harus berjuang keras untuk meningkatkan efisiensi yang dimiliki. Pada saat ini perusahaan mengalami tingkat kehilangan bahan baku kain dalam proses produksi (waste). Hal ini dikarenakan jumlah defect melebihi batasan target perusahaan yaitu, $3 \%$.

Upaya perbaikan kualitas produk merupakan tujuan dari perbaikan proses demi mencapai kepuasan pelanggan. Tahap define (DMAIC) dilakukan Value stream mapping untuk mengetahui waste yang terjadi. Dilanjutkan dengan Measure untuk menghitung kinerja sigma dan analyze dengan tool VALSAT.Pada tahap Improve implementasi Theory of Inventive Problem Solving berperan untuk menyelesaikan kompleksitas permasalahan yang terjadi berdasarkan sumber daya yang ada.

\subsection{Tujuan Penelitian}

1. Mengidentifikasi jenis waste dan bagian proses mana yang berpengaruh terhadap waste tersebut.

2. Menghasilkan solusi potensial untuk meningkatkan kualitas produk sepatu yang diproduksi PT. Unggul Makmur Sejahtera.

\subsection{Studi Literatur}

Lean adalah perampingan atau efisiensi suatu proses. Dikemukakan pertama kali oleh Taiichi Ohno dan Shigeo Shingo pada sistem produksi Toyota Jepang, prinsip ini kemudian dikenal sebagai Lean Manufacturing. Lean manufacturing merupakan pendekatan secara sistematis untuk mengidentifikasi dan mengeleminasi waste melalui continuous improvement, aliran produk ditarik oleh customer demi mencapai kesempurnaan (NIST, 2000). Dasar pemikiran dari pendekatan Lean thinking adalah melakukan perbaikan kecepatan proses dan mengurangi biaya dengan menghilangkan waste (pemborosan) baik dalam tubuh perusahaan atau antar perusahaan.
Kata Sigma diambil dari sebuah huruf dalam alphabet Yunani $\sigma$, dan digunakan dalam ilmu statistik sebagai sebuah ukuran variasi. Sigma adalah ukuran kemampuan proses untuk menghasilkan produk yang sempurna tanpa cacat. Nilai Sigma mengidentifikasikan seberapa sering kecacatan dapat terjadi. Tujuan statistik Six Sigma adalah untuk mengurangi variasi output proses sehingga $\pm 6 \sigma$ berada dalam batas atas dan batas bawah spesifikasi (USL dan LSL). Dengan menjaga agar jarak rata-rata proses dengan batas spesifikasi terdekatnya adalah sebesar $6 \sigma$, maka output yang keluar dari spesifikasi tidak akan lebih dari 3.4 dalam setiap satu juta peluang (Defect Per Million Oppotunities-DPMO / Parts per million-ppm defective).

\subsection{METODE}

Penelitian ini dibagi menjadi 4 tahapan, yaitu

1. Penelitian awal yang terdiri dari identifikasi masalah, tujuan penelitian, pengamatan di perusahaan, studi pustaka dan pengumpulan data.

2. Pengolahan data yang terdiri dari tahap Define dan Measure. Tahap Define terdiri dari pemetaan Value stream kondisi awal, Diagram Supplier Input Process Output Customer (SIPOC), brainstroming dan penyebaran kuisoner. Sedangkan tahap Measuredilakukan perhitungan kapabilitas proses dan kinerja sigma perusahaan.

3. Analisis data merupakan tahap Analyze yaitu, menentukan waste terbesar dengan tools VALSAT, diagram pareto, Failure Modes Effect Analysis, diagram Root-cause dan sebab akibat.Tahap improve adalah solusi perbaikan yang dihasilkan dan implementasi TRIZ untuk mendapatkan solusi. Tahap control merupakan hasil yang dicapai setelah implementasi perbaikan.

4. Kesimpulan dan saran.

\section{HASIL DAN PEMBAHASAN Define}

Pada bagian produksi terdapat current state value stream yang merupakan kondisi awal perusahaan. Terdapat 2 macam alur dalam mapping tersebut, yaitu alur informasi dan alur material untuk produksi. Alur informasi berkaitan dengan proses komunikasi antara beberapa department terkait dan supplier ataupun customer, seperti PPIC, Marking Design, upper production, Cutting, warehouse, finishing. Sedangkan alur material berkaitan dengan proses produksi sepatu group $\mathrm{BIOM}$ itu sendiri, dimulai dari pemenuhan kebutuhan material berupa component, leather, direct material dari warehouse, kemudian dikirim ke proses cutting. Dalam Kemudian material - material tersebut dikirim ke area stitching, Sewing,finishing dan Packing. Langkah-langkah yang dilakukan dalam pembuatan current state VSM adalah sebagai berikut:

1. Mengidentifikasi dan memetakan semua proses yang terlibat dalam proses pembuatan garment mulai dari PPIC, Marking Design, upper production, Cutting, warehouse, finishing.. 
2. Menggambarkan masing-masing proses di VSM dan mengidentifikasikan arah informasi dan jenis informasi dari tiap proses yang ada.

3. Memasukkan data waktu standar (value time), jumlah stock antara proses dan jumlah operator.

4. Memasukkan data customer demand per hari, waktu yang dibutuhkan dalam satu hari dan menghitung takt time di proses tersebut.

Customer demand $=1013 \mathrm{prs} / \mathrm{day}$

Available time $=435$ minutes $\times 3 \times 60=78300 \mathrm{~s}$

Takt time $=\frac{\text { available time }}{\text { customer demand }}$

Takt time $=\frac{78300 \mathrm{~s}}{1013 \mathrm{prs} / \mathrm{day}}=77.29 \mathrm{~s}$

5. Mengkonversikan jumlah stock kedalam waktu dengan sebagai berikut:

Stock sebelum component $=2016$ prs

Lead time stock $=\frac{\text { stock }}{\text { demand per day }}=\frac{2016 \mathrm{prs}}{1013 \mathrm{prs} / \mathrm{day}}=1.99$ days

6. Membuat diagram waktu value added time dan non value added time dibagian bawah VSM. Kemudian menghitung bila VAR, dengan rumus berikut:

$$
\begin{aligned}
& \text { Value added ratio }=\frac{\text { value added time (process time) }}{\text { non value added time (lead time) }} \times 100 \% \\
& =\frac{74.095 \mathrm{mnt}}{12866 \mathrm{mnt}} \times 100 \%=0.575 \%
\end{aligned}
$$

Setiap proses memungkinkan terjadinya kehilangan bahan baku, kehilangan bahan baku disini berupa produk defect yang diketahui setelah proses terakhir dilakukan. Gambaran lebih detail mengenai proses kunci dan pelanggannya.

\subsection{Measure}

Kapabilitas proses dapat dilihat kalau nilai $\mathrm{C}_{\mathrm{pk}}$ dari proses ini adalah sebesar 0.66. Berdasarkan kriteria indeks kapabilitas yang standar, nilai ini tidak mampu memenuhi kriteria standar proses yang baik $\left(C_{p k}\right.$ minimum 1)

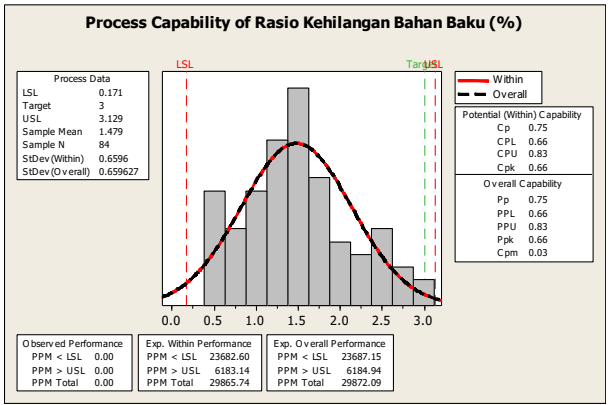

Gambar 1. Kapabilitas proses dari kehilangan bahan baku

Dari nilai dan gambar 1 dapat dilihat kalau proses memiliki kecenderungan untuk mendekati nilai batas atas. Hal ini berarti proses memberikan peluang untuk beroperasi melebihi batas atas sehingga besar kemungkinan proses semakin sulit untuk mencapai target bahkan ada juga kemungkinan nilai rasio kehilangan bahan baku berada di atas batas spesifikasi yaitu di atas $3.129 \%$.

Dari hasil perhitungan tersebut, dapat diambil kesimpulan bahwa meskipun proses berada dalam kondisi stabil akan tetapi kemampuan proses untuk mencapai target masih kecil. Oleh karena itu sesuai dengan konsep kapabilitas maka perusahaan ini sangat membutuhkan adanya peningkatan proses.

Berikut ini merupakan hasil perhitungan pengukuran kinerja sigma.

Tabel 1. Hasil Perhitungan Nilai DPMO dan Level

\begin{tabular}{|c|c|c|c|}
\hline \multicolumn{4}{|c|}{\begin{tabular}{|l}
\multicolumn{2}{|c|}{ Kapabilitas Sigma Proses Produksi } \\
CTQ-Jumlah Lost Material per siklus produksi \\
dalam satuan \%
\end{tabular}} \\
\hline No & Tindakan & Simbo & \begin{tabular}{|l} 
Hasil \\
Perhitungan
\end{tabular} \\
\hline 1 & $\begin{array}{l}\text { Proses yang ingin } \\
\text { diket }\end{array}$ & - & $\%$ kehilangar \\
\hline 2 & \begin{tabular}{|l|}
$\begin{array}{l}\text { Nilai batas } \\
\text { spesifikasi atas }\end{array}$ \\
\end{tabular} & USL & $\begin{array}{l}3.129 \% \mathrm{dar} \\
\text { total material }\end{array}$ \\
\hline 3 & $\begin{array}{l}\text { Nilai batas } \\
\text { spesifikasi bawah }\end{array}$ & LSL & $\begin{array}{l}0.171 \% \text { dar } \\
\text { total material }\end{array}$ \\
\hline 4 & Nilai target & $\mathrm{T}$ & $\begin{array}{l}3 \% \text { dari totatale } \\
\text { material }\end{array}$ \\
\hline 5 & $\begin{array}{l}\text { Nilai rata-rata } \\
\text { noress }\end{array}$ & $\mathrm{x}$-bar & $1.48 \%$ \\
\hline 6 & $\begin{array}{l}\text { Nilai standar } \\
\text { deviasi }\end{array}$ & $\mathrm{s}$ & $0.66 \%$ \\
\hline 7 & $\begin{array}{l}\text { Defect per Milion } \\
\text { Opportunity yang }\end{array}$ & DPMO & 6200 \\
\hline 8 & $\begin{array}{l}\text { Konversi nilai } \\
\text { DPMO ke nilai } \\
\text { sigma }\end{array}$ & - & $6210=4.00$ \\
\hline 9 & $\begin{array}{l}\text { Kemampuan } \\
\text { proses dalam } \\
\text { ukuran nilai sigma }\end{array}$ & - & 4 \\
\hline
\end{tabular}
Sigma

\subsection{Analyze}

Pada tahap ini dilakukan pembobotan hasil waste dari kuisoner identifikasi waste yang telah disebar. Tabel 2hasil perhitungan tools VALSAT menunjukkan bahwa waste terbesar yang terjadi adalah defect dan unnecessary inventories sedangkan tools yang digunakan adalah Process Activity Mapping.

\begin{tabular}{|c|c|c|c|c|c|c|c|c|c|}
\hline \multirow{2}{*}{ No. } & \multirow{2}{*}{ Waste } & \multirow{2}{*}{ Bobot } & \multicolumn{7}{|c|}{$\begin{array}{l}\text { VALSAT } \\
\end{array}$} \\
\hline & & & PAM & SCRM & PVF & QFM & DAM & DPA & PS \\
\hline 1 & Defect & 4.43 & 4.43 & 0.00 & 0.00 & 39.86 & \begin{tabular}{|l|}
0.00 \\
\end{tabular} & \begin{tabular}{|l|}
0.00 \\
\end{tabular} & 0.00 \\
\hline 2 & $\begin{array}{l}\text { Unnecessary } \\
\text { Inventories }\end{array}$ & 4.00 & 12.00 & 36.00 & 4.00 & 0.00 & 36.00 & 12.00 & 4.00 \\
\hline 3 & $\begin{array}{l}\text { Inapropriate } \\
\text { process }\end{array}$ & 3.57 & 32.14 & 0.00 & 10.71 & 3.57 & 0.00 & 3.57 & 0.00 \\
\hline 4 & Waiting & 3.14 & 28.29 & 28.29 & 3.14 & 0.00 & \begin{tabular}{|l|}
9.43 \\
\end{tabular} & \begin{tabular}{|l|}
9.43 \\
\end{tabular} & 0.00 \\
\hline 5 & Over production & 2.86 & 2.86 & 8.57 & 0.00 & 2.86 & 8.57 & 8.57 & 0.00 \\
\hline 6 & Transportation & 2.43 & 21.86 & 0.00 & 0.00 & 0.00 & 0.00 & \begin{tabular}{|l|}
0.00 \\
\end{tabular} & 2.43 \\
\hline 7 & \begin{tabular}{|l|} 
Unnecessary \\
Motion
\end{tabular} & 1.57 & 14.14 & 1.57 & 0.00 & 0.00 & 0.00 & 0.00 & 0.00 \\
\hline & TOTAL SKOR & & 115.71 & 74.43 & 17.86 & 46.29 & 54.00 & \begin{tabular}{|l|}
33.57 \\
\end{tabular} & 6.43 \\
\hline
\end{tabular}

Tabel 2.Perhitungantools VALSAT

Hasil PAM diperoleh jumlah aktifitas untuk setiap pengelompokkan aktifitas dengan prosentase masing-masing seperti tabel 3. Inventories merupakan waste dengan waktu yang lama.

Tabel 3. Prosentase Jumlah Aktifitas

\begin{tabular}{|c|l|c|c|}
\hline No. & Aktifitas & Waktu (Menit) & $(\%)$ \\
\hline 1 & Operation & 59.99 & 0.68 \\
\hline 2 & Transport & 0.10 & 0.00 \\
\hline 3 & Delay & 66.05 & 0.75 \\
\hline 4 & Inventory & 8646.00 & 98.55 \\
\hline 5 & Inspection & 1.30 & 0.01 \\
\hline
\end{tabular}


Hasil analisa dengan diagram pareto dapat ditunjukkan pada gambar 2. Sedangkan penyebab utama defect adalah Over roughing dan $2^{\text {nd }}$ injection.

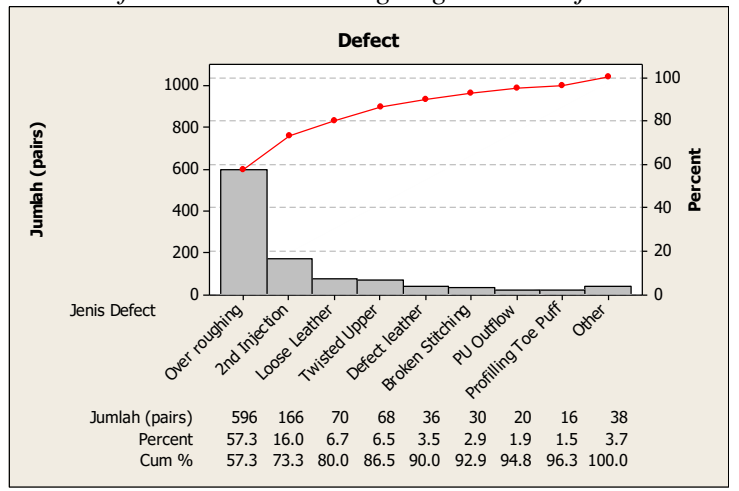

Gambar 2. Diagram Pareto Defect periode MeiNovember 2013

\subsection{Improve}

Perbaikan dalam upaya mengurangi waste yang terjadi adalah dengan penerapan future value stream sedangkan perbaikan kualitas adalah dengan theory of inventive problem solving (TRIZ). Adapun beberapa usulan perbaikan dapat dilihat pada tabel 4 .

Tabel 4.Root cause dan Usulan perbaikan

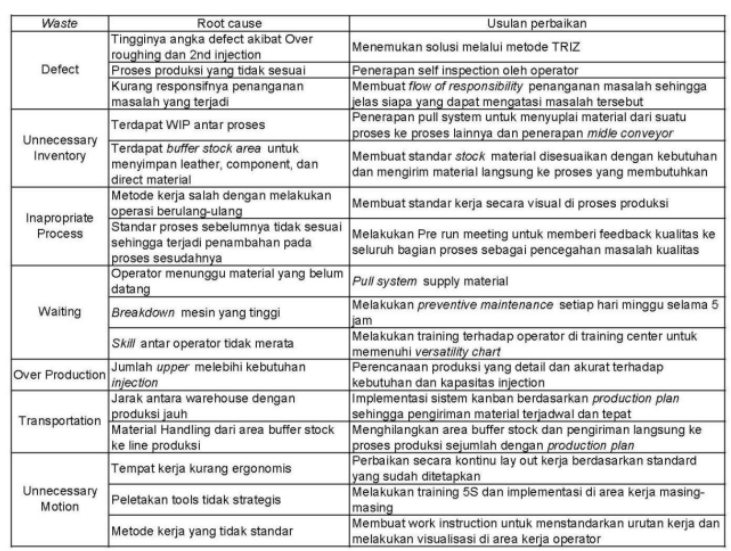

Penerapan metode TRIZ untuk menyelesaikan masalah pada faktor mesin, yaitu setting neddle (jarum) dan motor mesin tidak diupdate. Sedangkan pada permasalah faktor material, yaitu viscosity tidak sesuai dengan spesifikasi dan faktor mesin.

Detail solusi TRIZ, adalah penggunaan alarm dan lampu sebagai signal bila program supervisor tidak diganti ketika terjadi penggantian size atau mould, selain itu di masing - masing operator sewing dapat memberi tahu mekanik mesin jika mesinnya ada kerusakan

\subsection{Control}

Pada penelitian diberikan masukan kepada perusahaan mengenai cara pengendalian dan pengawasan proses produksi garmen yang memiliki tingkat defect yang tinggi, terutama pada bagian quality control. Nilai VAR mengalami kenaikan dari $0.575 \%$ menjadi $1.06 \%$ dan kinerja sigma setelah perbaikan mencapai 6 sigma.

\section{KESIMPULAN DAN SARAN}

Dari hasil penelitian yang dilakukan yaitu penerapan metodologi Lean Six Sigma untuk mengurangi waste dan memperbaiki kualitas, dapat ditarik kesimpulan dan saran sebagai berikut :

1. Dari waste workshop diketahui waste terbesar yang terjadi pada PT Unggul, Makmur Sejahtera adalah Defect, Unnecessary Inventories, Inapropriate process, Waiting, over production, transportation, dan Motion. Bagian proses yang menjadi penyebab waste tersebut adalah

a. Waste Defect : Proses produksi yang tidak sesuai sehingga menghasilkan Over roughing dan 2nd injection, dan penanganan masalah yang terjadi kurang responsif.

b. Waste unnecessary inventories : Terdapat hambatan antar proses dan buffer stock area untuk menyimpan leather, component, dan direct material.

c. Waste inappropriate process : Metode kerja salah dengan melakukan operasi berulangulang dan standar proses sebelumnya tidak sesuai sehingga terjadi penambahan pada proses sesudahnya.

d. Waste Waiting : Operator menunggu material yang belum datang, breakdown mesin yang tinggi, dan skill antar operator tidak merata.

e. Waste over production : Jumlah upper melebihi kebutuhan injection.

f. Waste transportation : Jarak antara warehouse dengan produksi jauh dan material Handling dari area buffer stock ke line produksi.

g. Waste motion : Tempat kerja kurang ergonomis, peletakan tools tidak strategis, dan metode kerja yang tidak standar.

2. Penerapan perbaikan dengan metode TRIZ untuk mengatasi masalah kualitas yaituover roughing dan $2^{\text {nd }}$ injectionadalah penggunaan alarm dan lampu sebagai signal bila program supervisor tidak diganti ketika terjadi penggantian size atau mould, selain itu di masing - masing operator sewing dapat

3. memberi tahu mekanik mesin jika mesinnya ada kerusakan

4. Saran kepada perusahaan tentang usaha mengurangi waste dan peningkatan kualitas sebagai berikut :

a. Sangat penting untuk memperhatikan kelanjutan pengkuran kinerja proses, untuk itu disarankan agar departemen Cutting dan warehouse dapat membantu tim produksi.

b. Pengembangan SDM dengan pelatihan kualitas sangat diperlukan, karena masalah yang terjadi kebanyakan disebabkan oleh ketidakpahaman operator atau supervisor dalam mengatasi masalah yang ada.

Bagi peneliti lain yang tertarik untuk mengambil topik yang sama, disarankan agar berupaya 
untuk menghitung keuntungan finansial perusahaan terhadap perbaikan yang telah diimplememtasikan.

5. DAFTAR PUSTAKA

[1] Brue, Greg dan Rod Howes (2006). "The McGrawHill 36-Hours Cource Six Sigma".McGrawHill, New York.

[2] Bligh, Amanda (2006). "The Overlap between TR and Lean". IME 552: Lean Manufacturing Systems. University Of Rhode Island.

[3]Domb, A (1997). A Methodology for creativity, California.

[4] Domb, E (1997). "The 39 features of Alsthullers contradiction matrix". TRIZ journal 1997/11

[5] Hines, Peter \& Rich, Nick (1997). "The seven value stream mapping tools". Lean Enteprises research center, Cardiff Bussines School, Cardiff, UK. International Journal of Operation and Production Management, Vol. 1, No. 1, pp. 46-04.

[6] Hines, Peter \& Rich, Nick (2001). "The seven value stream mapping tools". Manufacturing operation and supply chain management: The Lean Approach, eds. Taylor, D \& Brunt, D., Thompson Learning, London.

[7] Jugulum, Rajesh dan Samuel, Philip (2008). "Design for lean six sigma". John Wiley \& Sons, Inc, New J 